\title{
SURVEY OF THE MOST LEPIDOPTEROUS MOTHS ATTRACTED TO A LIGHT-TRAP AT TWO REGIONS IN EGYPT
}

\author{
El- Saeady
}

and M. M. M. E. Megahed ${ }^{1}$

${ }^{1}$ Dept. of Plant Protection. Fac. Of Agric. Al-Azhar Univ. Cairo. Egypt.

${ }^{2}$ Plant Protection. Res. Inst., Agric., Res. Center, Dokki, Egypt.

\begin{abstract}
Thirty-nine species belonged to eleven families were trapped in Nasr city (Cairo). The total numbers of trapped moths throughout the two years (2007\&2008) were 23340 specimens. The total numbers of moths were 12646 individuals during the first year, while it was lower in the second year (10694 moths).

Fourty-five species belonging to eleven lepidopterous families were recorded in Motobas region. The total numbers of moths during two years were 26483 moths. The total numbers of moths during the first year were 13680 moths and 12803 moths during the second year.

Family Noctuidae was the most abundant family in both number of species (16 and 19 species) and number of individuals, 9578 moths representing $41.04 \%$ and 13868 moths constituting $52.37 \%$ of the total Lepidopterous catch in Nasr city and Motobas respectively.

Spodoptera littoralis was the most abundant species, in all families in both regions. Individuals of this species (3878 moths represented $16.62 \%$ and 5759 moths represented $21.75 \%$ of the total lepidopterous catch in Nasr city and Motobas respectively.
\end{abstract}

\section{INTRODUCTION}

Studying the phenological aspects are very important way to follow up many relationships between environmental factors and population subjects for any group of insects. These subjects are: existence, population dynamics, population fluctuation, seasonal activity, number of generations.

Concerning the Egyptian ecosystem, distinctly changed in the latter years for many seasons which includes, planting of new crops in the new reclaimed lands, resistant and early maturing crops, destructing and harvesting of crops and weeds, solarization and irrigation.

The study of the lepidopterous fauna is very important for all biological, ecological and for extension and pests management programs.

The present work was carried out at two important regions in Egypt: Motobas district, Kafr El-Shiekh Governorate, and the Farm of the Faculty of Agriculture, Al-Azhar University at Nasr city, Cairo. The study lasted two successive years extending from January, 2007 and continued to the end of December 2008 by using usual light-trap (Robinson type).

The isolation of the species and specimens, counting and identification take place in two the laboratories one in the Faculty of Agriculture, Al-Azhar University, Nasr city, Cairo and the other one is in the Classification Research Department (Plant Protection Research Institute, 
Dokki, Giza) by the help of the Revisional Collection in the previous department. Some of the good specimens have been pinned and preserved in our lateral Collection for future studies and for enhancing the lepidopterous Alfieri Collection in our department (Faulty of Agriculture).

This work was planned to follow up the speciation and count of the attracted lepidopterous moths species.

\section{MATERIALS AND METHODS}

The aim of the present part is to determine how to management the different methods for obtaining all and accurate data-base for all phenological aspects.

\section{1- Site and location of work}

The first step is to choose the site of work, why "Nasr city" and Kafr El-Sheikh ecosystem. We know that insect exist in all parts of our life, in houses, stores, warehouses, granaries, in the fields, in water-streams and ponds.

The first site of work was the farm of the faculty of Agriculture, AlAzhar University at Nasr city east of great Cairo as a semi-desert area, that densely populated. The farm cultivated with numerous field crops, orchards, ornamental and medicinal plants, fiber plants, roses, vegetables, shrubs, weeds and trees. Also the whether and climatic condition are very difficult as a desert area which may effect in the speciation of the inhibiting lepidopterous species.

The second location is (Motobas) district in Kafr El-Sheikh Governorate (Northern of Delta) was chosen as old cultivated area specialized for field crops and other plants of great economic importance. The two sites are surveying as Delta ecosystem.

\section{2- Method of collection}

The second step is to determine firmly the real methods of collecting and surveying of moths. So, the use of the ideal "Robinson type" light-trap which provided with "250 watt" ultra-violet, mercury-vapour lamp had been chosen.

The light-trap container jar of "calcium cyanide" for quick killing insect especially moths of Lepidoptera. The trap was operated and fixed on any governmental building of three meters high above the ground, and this high is very suitable for good attractant to the flying moths.

The time of operate the trap is very important to reach the good results of trapping moth. So, the trap was start work from dust (sunset period, and reaching to down time daily and automatically operated for two successive years starting from the first of January 2007 and reached to the end of December 2008.

The collecting of the attracted moths have been daily gathering in paper sac provided by fine paper stripes to prevent the moisture, molding and breakage throughout the "cyanide jar or within the preserving sac before the separation process. 


\section{3- Isolation and identification process}

The third step is to start the isolation and separation of the attracted moths in the laboratories. This step had been done in two main laboratories, the first was in "the Taxonomic laboratory" in the Classification Research Department in the Plant Protection Research Institute (Ministry of Agriculture, Dokki, Giza, Egypt), while the second one was in the Plant Protection Department in the Faculty of Agriculture (Al- Azhar University- Nasr city, Cairo). The identification of the lepidopterous species have been achieved in the two laboratories by the technical assistance of the supervisor Prof. Dr. Moustafa Ahmed Badr, who is specialized in the taxonomy of lepidopterous species, and in that time by using the two main insect Collections, the Revisitonal Insect Collection of the Classification Research Department and Alfieri Collection in Plant Protection Department Faculty of Agriculture, AlAzhar University.

The counting of moth specimens have been finished directly after isolation and identification process. The counting and number of every species have been tabulated in special tables and weekly enhanced.

\section{RESULTS AND DISCUSSION}

As shown in Table (1) thirty-nine lepidopterous species belonged to eleven families were trapped in Nasr city (Cairo). The total numbers of trapped moths throughout the two years were 23340 specimens. The total numbers of moths were 12646 individuals during the first year, while it was lower in the second year (10694 moths). Ibrahim (1977) in a similar study found 20 species in Nasr city.

Table (2) presented a survey of attracted Lepidopterous moths in Motobas region. It included forty-five species that belonging to eleven lepidopterous families. The total numbers of moths during two years were 26483 moths. The largest number of moths were lured during the first year (13680 moths), while it was (12803 moths) in the second year. Zanaty et al. (1985) found forty species belonging to eight families at Kafr El-Shiekh region.

The occurrence of the determined families could be indicated as the follow:

\section{Fam.: Cosmopterygidae}

This family was represented by two species with a total number of 2248 and 2770 during two years in Nasr city and Motobas respectively, Table (1\&2). Sathrobrota rileyi moths were the most abundant within family Cosmopterygidae. About 1498 and 1947 moths of this species were trapped during two years, this number formed $6.42 \%$ and $7.35 \%$ of the total Lepidopterous moths in Nasr city and Motobas respectively. The species Cosmopteryx mimetes was the second cosmopterygid insect according to its flight activity. Its total lured number during the two years were 750 and 823 moths, this numbers representing $3.21 \%$ and $3.11 \%$ of the total catch in Nasr city and Motobas respectively. The two species were captured for the first time by using light-traps in the two regions. 
El- Saeady, A. A. et al.

Table (1): The total number and percentages of some flight Lepidopterous species obtained during the two investigated years (2007 \&2008) in Nasr city.

\begin{tabular}{|c|c|c|c|c|c|c|}
\hline \multirow[b]{2}{*}{ Families \& Species } & \multirow{2}{*}{\multicolumn{2}{|c|}{$\begin{array}{c}\text { first year } \\
\text { Catch }\end{array}$}} & \multirow{2}{*}{\multicolumn{2}{|c|}{$\begin{array}{c}\text { second year } \\
\text { Catch }\end{array}$}} & \multicolumn{2}{|c|}{ 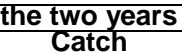 } \\
\hline & Total & & & & & Total \\
\hline \multicolumn{7}{|l|}{ Fam. Cosmopterygidae } \\
\hline Cosmobteryx mimetes Meyrick & 269 & 2.13 & 481 & 4.50 & 750 & 3.21 \\
\hline Sathrobrota rileyi (Walsingham) & 752 & 5.95 & 746 & 6.98 & 1498 & 6.42 \\
\hline Total & 1021 & 8.07 & 1227 & 11.47 & 2248 & 9.63 \\
\hline \multicolumn{7}{|l|}{ Fam. Gelechildae } \\
\hline Aproaerema anthyllidella (H.) & 1068 & 8.45 & 1318 & 12.32 & 2386 & 10.22 \\
\hline Pectinophora gossypiella (Saunders) & 516 & 4.08 & 495 & 4.63 & 1011 & 4.33 \\
\hline Total & 1584 & 12.53 & 1813 & 16.95 & 3397 & 14.55 \\
\hline \multicolumn{7}{|l|}{ Fam. Geometridae } \\
\hline Chlorissa faustinata Milliere & 213 & 1.68 & 15 & 0.14 & 228 & 0.98 \\
\hline Scopula adelpharia pharaonis Sterneck & 423 & 3.34 & 406 & 3.80 & 829 & 3.55 \\
\hline Scopula donovani (Distant) & 695 & 5.50 & 344 & 3.22 & 1039 & 4.45 \\
\hline Total & 1331 & 10.53 & 765 & 7.15 & 2096 & 8.98 \\
\hline \multicolumn{7}{|l|}{ Fam. Lemoniidae } \\
\hline Lemonia philopalus Panzer & 73 & 0.58 & 60 & 0.56 & 133 & 0.57 \\
\hline \multicolumn{7}{|l|}{ Fam.Lyonetifdae } \\
\hline Lyonetia clerkella (L.) & 147 & 1.16 & 95 & 0.89 & 242 & 1.04 \\
\hline \multicolumn{7}{|l|}{ Fam. Noctuidae } \\
\hline Agrotis ipslion (Huf) & 224 & 1.77 & 212 & 1.98 & 436 & 1.87 \\
\hline Agrotis spinifera (H.) & 254 & 2.01 & 257 & 2.40 & 511 & 2.19 \\
\hline Autographa gamma (L.) & 236 & 1.87 & 178 & 1.66 & 414 & 1.77 \\
\hline Chrysodiexis chalacytes (Esper) & 128 & 1.01 & 108 & 1.01 & 236 & 1.01 \\
\hline Earias insulana (Boisd.) & 188 & 1.49 & 114 & 1.07 & 302 & 1.29 \\
\hline Eublemma gayneri Rotheschild & 380 & 3.00 & 295 & 2.76 & 675 & 2.89 \\
\hline Grammodes boisdeffre Oberthur & 91 & 0.72 & 71 & 0.66 & 162 & 0.69 \\
\hline Helicoverpa armigera (H.) & 149 & 1.18 & 136 & 1.27 & 285 & 1.22 \\
\hline Heliothis peltigera (Denis \& Schiffer.) & 96 & 0.76 & 104 & 0.97 & 200 & 0.86 \\
\hline Noctua pronuba L. & 158 & 1.25 & 144 & 1.35 & 302 & 1.29 \\
\hline Scotogramma trifolii (Huf.) & 83 & 0.66 & 70 & 0.65 & $15 \overline{3}$ & 0.66 \\
\hline Sesamia cretica Led. & 293 & 2.32 & 195 & 1.82 & 488 & 2.09 \\
\hline Spodoptera exigua (H.) & 324 & 2.56 & 332 & 3.10 & 656 & 2.81 \\
\hline Spodoptera littoralis (Boisd.) & 2308 & 18.25 & 1570 & 14.68 & 3878 & 16.62 \\
\hline Spodoptera latebrosa Led. & 411 & 3.25 & 277 & 2.59 & 688 & 2.95 \\
\hline Thysanoplusia orichalcea (F.) & 97 & 0.77 & 95 & 0.89 & 192 & 0.82 \\
\hline Total & 5420 & 42.86 & 4158 & 38.88 & 9578 & 41.04 \\
\hline \multicolumn{7}{|l|}{ Fam. Oecophoridae } \\
\hline Depressaria straminella (Stgr.) & 276 & 2.18 & 322 & 3.01 & 598 & 2.56 \\
\hline \multicolumn{7}{|l|}{ Fam. Plutellidae } \\
\hline Plutella xylostella (L.) & 849 & 6.71 & 629 & 5.88 & 1478 & 6.33 \\
\hline \multicolumn{7}{|l|}{ Fam. Pyralidae } \\
\hline Etiella zinckenella (Treit.) & 106 & 0.84 & 103 & 0.96 & 209 & 0.90 \\
\hline Euchromius cambridgei Zeller & 142 & 1.12 & 190 & 1.78 & 332 & 1.42 \\
\hline Pyralis galactalis Haworth & 1 & 0.01 & 1 & 0.01 & 2 & 0.01 \\
\hline Total che & 249 & 1.97 & 294 & 2.75 & $5 \overline{43}$ & 2.33 \\
\hline \multicolumn{7}{|l|}{ Fam. Pyraustidae } \\
\hline Herptogramma licarsisalis (Walker) & 274 & 2.17 & 271 & 2.53 & 545 & 2.34 \\
\hline Hymenia recurvalis (F.) & 340 & 2.69 & 263 & 2.46 & 603 & 2.58 \\
\hline Nomophila noctuella (Denis\& Schiffer.) & 436 & 3.45 & 253 & 2.37 & 689 & 2.95 \\
\hline Noctuelia floralis (H.) & 118 & 0.93 & 120 & 1.12 & 238 & 1.02 \\
\hline Ostrinia nubilalis (H.) & 222 & 1.76 & 178 & 1.66 & 400 & 1.71 \\
\hline Palpita unionalis (H.) & 135 & 1.07 & 102 & 0.95 & 237 & 1.02 \\
\hline Pyrausta sanguinalis (L.) & 129 & 1.02 & 86 & 0.80 & 215 & 0.92 \\
\hline Total on & 1654 & 13.08 & 1273 & 11.90 & 2927 & 12.54 \\
\hline \multicolumn{7}{|l|}{ Fam. Sphingidae } \\
\hline Agrius convolvuli convolvuli (L.) & 9 & 0.07 & 11 & 0.10 & 20 & 0.09 \\
\hline Hyles lineata livorinica (Esper) & 33 & 0.26 & 47 & 0.44 & 80 & 0.34 \\
\hline Total & 42 & 0.33 & 58 & 0.54 & 100 & 0.43 \\
\hline Total catch & 12646 & 100 & 10694 & 100 & 23340 & 100 \\
\hline
\end{tabular}


Table (2): The total number and percentages of some flight lepidopterous species obtained during the two investigated years (2007 \&2008) in Motobas district.

\begin{tabular}{|c|c|c|c|c|c|c|}
\hline \multirow{2}{*}{$\begin{array}{l}\text { Families } \\
\& \\
\text { Species }\end{array}$} & \multicolumn{2}{|c|}{$\begin{array}{c}\text { first year } \\
\text { Catch }\end{array}$} & \multicolumn{2}{|c|}{$\begin{array}{c}\text { second year } \\
\text { Catch }\end{array}$} & \multicolumn{2}{|c|}{$\begin{array}{c}\text { the two years } \\
\text { Catch }\end{array}$} \\
\hline & Total & $\%$ & Total & & & \\
\hline \multicolumn{7}{|l|}{ Fam. Cosmopterygidae } \\
\hline Cosmopteryx mimetes Meyrick & 379 & 2.77 & 444 & 3.47 & 823 & 3.11 \\
\hline Sathrobrota rileyi(Walsingham) & 898 & 6.56 & 1049 & 8.19 & 1947 & 7.35 \\
\hline Total & 1277 & 9.33 & 1493 & 11.66 & 2770 & 10.46 \\
\hline \multicolumn{7}{|l|}{ Fam. Cossidae } \\
\hline Phragmataecia castanea (H.) & 73 & 0.53 & 58 & 0.45 & 131 & 0.49 \\
\hline Zeuzera pyrina (L.) & 14 & 0.10 & 9 & 0.07 & 23 & 0.09 \\
\hline Total & 87 & 0.64 & 67 & 0.52 & 154 & 0.58 \\
\hline \multicolumn{7}{|l|}{ Fam. Gelechidiae } \\
\hline Pectinophora gossypiella(Saunders) & 267 & 1.95 & 247 & 1.93 & 514 & 1.94 \\
\hline \multicolumn{7}{|l|}{ Fam. Geometridae } \\
\hline Chlorissa faustinata Milliere & 24 & 0.18 & 31 & 0.24 & 55 & 0.21 \\
\hline Rhodometra sacraria (L.) & 209 & 1.53 & 327 & 2.55 & 536 & 2.02 \\
\hline Scopula adelpharia pharaonis Sterneck & 282 & 2.06 & 277 & 2.16 & 559 & 2.11 \\
\hline Total & 515 & 3.76 & 635 & 4.96 & 1150 & 4.34 \\
\hline \multicolumn{7}{|l|}{ Fam. Lemoniidae } \\
\hline Lemonia philopalus Panzer & 72 & 0.53 & 85 & 0.66 & 157 & 0.59 \\
\hline \multicolumn{7}{|l|}{ Fam. Noctuidae } \\
\hline Agrotis ipsilon (Huf) & 257 & 1.88 & 252 & 1.97 & 509 & 1.92 \\
\hline Agrotis spinifera (H.) & 149 & 1.09 & 170 & 1.33 & 319 & 1.20 \\
\hline Athetis clavipalips Scopoli & 122 & 0.89 & 180 & 1.41 & 302 & 1.14 \\
\hline Autographa gamma (L.) & 260 & 1.90 & 219 & 1.71 & 479 & 1.81 \\
\hline Chrysodeixis chalcites (Esper) & 191 & 1.40 & 135 & 1.05 & 326 & 1.23 \\
\hline Earias insulana (Boisd.) & 202 & 1.48 & 145 & 1.13 & 347 & 1.31 \\
\hline Eublemma gayneri Rotheschild & 398 & 2.91 & 312 & 2.44 & 710 & 2.68 \\
\hline Eublemma scitula (Rambur) & 67 & 0.49 & 284 & 2.22 & 351 & 1.33 \\
\hline Grammodes boisdeffrei Oberthur & 109 & 0.80 & 93 & $0 . \overline{3}$ & 202 & 0.76 \\
\hline Helicoverpa armigera (H.) & 197 & 1.44 & 171 & 1.34 & 368 & 1.39 \\
\hline Heliothis peltigera (Denis \& Schiffer.) & 205 & 1.50 & 133 & 1.04 & 338 & 1.28 \\
\hline Mythimna loreyi (Dup.) & 192 & 1.40 & 184 & 1.44 & 376 & 1.42 \\
\hline Noctua pronuba $\mathrm{L}$. & 292 & 2.13 & 243 & 1.90 & 535 & 2.02 \\
\hline Pseudaletia unipuncta (Haworth) & 64 & 0.47 & 192 & 1.5 & 256 & 0.97 \\
\hline Sesamia cretica Led. & 198 & 1.45 & 162 & 1.27 & 360 & 1.36 \\
\hline Spodoptera exigua (H.) & 623 & 4.55 & 509 & 3.98 & 1132 & 4.27 \\
\hline Spodoptera littoralis (Boisd.) & 3200 & 23.39 & 2559 & 19.99 & 5759 & 21.75 \\
\hline Spodoptera latebrosa Led. & 504 & 3.68 & 474 & 3.70 & 978 & 3.69 \\
\hline Syngrapha circumflexa (L.) & 140 & 1.02 & 81 & 0.63 & 221 & 0.83 \\
\hline total & 7370 & 53.87 & 6498 & 50.75 & 13868 & 52.37 \\
\hline \multicolumn{7}{|l|}{ Fam. Plutellidae } \\
\hline Plutella xyloslla (L.) & 893 & 6.53 & 576 & 4.50 & 1469 & 5.55 \\
\hline \multicolumn{7}{|l|}{ Fam. Pterophoridae } \\
\hline Pterophorus monodactylus (L.) & 1 & 0.01 & 1 & 0.01 & 2 & 0.01 \\
\hline \multicolumn{7}{|l|}{ Fam. Pyralidae } \\
\hline Chilo agamemnon Blesz. & 221 & 1.62 & 174 & 1.36 & 395 & 1.49 \\
\hline Etiella zinckenella (Treit.) & 125 & 0.91 & 107 & 0.84 & 232 & 0.88 \\
\hline Euchromius cambridgei Zeller & 175 & 1.28 & 179 & 1.40 & 354 & 1.34 \\
\hline Lepidogma obatralis Christoph & 183 & 1.34 & 210 & 1.64 & 393 & 1.48 \\
\hline Schoenobius niloticus Zeller & 180 & 1.32 & 148 & 1.16 & 328 & 1.24 \\
\hline Total & 884 & 6.46 & 818 & 6.39 & 1702 & 6.43 \\
\hline Fam. Pyraustidae & & & & & & \\
\hline Herpetogramma licarsisalis (Walker) & 337 & 2.46 & 342 & 2.67 & 679 & 2.56 \\
\hline Hymenia recurvalis (F.) & 226 & 1.65 & 280 & 2.19 & 506 & 1.91 \\
\hline Nomophila noctuella (Denis\& Schiffer.) & 276 & 2.02 & 309 & 2.41 & 585 & 2.21 \\
\hline Noctuelia floralis (H.) & 283 & 2.07 & 307 & 2.40 & 590 & 2.23 \\
\hline Ostrinia nubilalis (H.) & 197 & 1.44 & 180 & 1.41 & 377 & 1.42 \\
\hline Palpita unionalis (H.) & 89 & 0.65 & 90 & 0.70 & 179 & 0.68 \\
\hline Pyrausta aurata Staudinger & 499 & 3.65 & 460 & 3.59 & 959 & 3.62 \\
\hline Pyrausta sanguinalis (L.) & 342 & 2.50 & 346 & 2.70 & 688 & 2.60 \\
\hline Total a & 2249 & 16.44 & 2314 & 18.07 & 4563 & 17.23 \\
\hline Fam. Sphingidae & & & & & & \\
\hline Agrius convolvuli convolvuli (L.) & 24 & 0.18 & 22 & 0.17 & 46 & 0.17 \\
\hline Hyles lineata livornica (Esper) & 41 & 0.30 & 47 & 0.37 & 88 & 0.33 \\
\hline Total & 65 & 0.48 & 69 & 0.54 & 134 & 0.51 \\
\hline Total catch & 13680 & 100 & 12803 & 100 & 26483 & 100 \\
\hline
\end{tabular}


2. Fam.: Cossidae

Two species of family Cossidae were found in the catches in Motobas (Table 2) in relatively low numbers of 131 and 23 moths the species Phragmataecia castanea and Zeuzera pyrina respectively representing $0.58 \%$ of the total catch of lepidopterous insect.

\section{Fam.: Gelechiidae}

Family Gelechiidae was represented in the catches by two species in Nasr city (Table 1), and only one species in Motobas (Table 2). The total catches of this family reached 3397 moths, representing $14.55 \%$ of the total Lepedopterous moths in Nasr city (Table 1). Aproaerema anthyllidella come in the second arrangement among of all species in Nasr city, this species was caught for the first time here; the total number of which reached 2386 moths formed $10.22 \%$ of the total catches of two years. The highest numbers of this species were 1318 moths representing $12.32 \%$ in the second year (Table 1). Pectinophora gossypiella come next in abundance among gelechiid moths (1011 moth) representing about $4.33 \%$ of total moths catches in Nasr city and (514 moth) formed $1.94 \%$ in Motobas. Ibrahim (1977) in Nasr city found only Pectinophora gossypiella, in gelechiid moths (463 moths) representing about $3.6 \%$ of the total moths catch during two years, Zanaty et al. (1985) in Kafr El-Shiekh recorded this insect (136 moths/ year).

\section{Fam.: Geometridae}

Family Geometridae was represented by four species in the two regions. The total number of geometrid moths reached 2096 moths and 1150 moths constituted $8.98 \%$ and $4.34 \%$ of the total Lepidopterous catches in Nasr city and Motobas respectively. Scopula donovani was the most abundant species (1039 moths, representing $4.45 \%$ of the lepidopterous catches in Nasr city, Table 1) and (559 moths forming about 2.11 of the moths catches in Motobas, Table 2). The large numbers of this species were caught in the first year 695 moths representing $5.5 \%$ of the total lepidopterous catches in Nasr city. The other three species were less abundant during this work.

\section{Fam.: Lemoniidae}

This family represented by only one species, Lemonia philopalus, with low numbers, the total numbers was 133 and 157 moths $(0.56 \%$ and $0.59 \%$ of the total catch) in Nasr city and Motobas respectively. The highest number of this species was 85 moths during the second year in Motobas. This species was recorded for the first time by using light-traps in Egypt.

\section{Fam: Lyonetiidae}

Table (1) showed that Family Lyonetiidae was represented by only one species, apple leafminer Lyonetia clerkella with total catch 242 moths, constituting $1.04 \%$ of the total lepidopterous catch, the highly numbers of this species was recorded during the first year 147 moths. This species was recorded for the first time by light-traps of collection.

\section{Fam.: Noctuidae}

Moths of family Noctuidae dominated the catch either in number of species or individuals. Sixteen species, 9578 moths representing $41.04 \%$ in Nasr city and 19 species, 13868 moths constituting $52.37 \%$ of the total Lepidopterous catch in Motobas. Ibrahim (1977), Badr et al. (1985a), Badr et 
al., (1985 b), Zanaty et al., (1985), El-Bassiouny et. al. (1997), Dall'-Asta (1997) and Nabli et. al. (1999) indicated that family Noctuidae was the most abundant family in both number of individuals and species. Some important species were chosen here to discuss their abundance.

Spodoptera littoralis was the most abundant species, in all families in both regions. Individuals of this species (3878 moths represented $16.62 \%$ and 5759 moths represented $21.75 \%$ of the total lepidopterous catch in Nasr city and Motobas respectively. The largest number (3200 moths) was trapped in the first year in Motobas, while the lowest number was (1570 moths) in the second year in Nasr city. Ibrahim (1977) in Nasr city found that $S$. littoralis was the most abundant species, in all families in Nasr City (2518 moths) and represent $19.7 \%$ of total catch in two years, Zanaty et al.(1985) found the same results in Kafr El-Shiekh (5349 moths/ year).

The next common noctuid species was, Spodoptera exigua, of total number 656 specimens, formed $2.81 \%$ of the total lepidopterous catch in Nasr city, Ibrahim (1977) in the same region found that S. exigua was (462 moths) and represent $3.6 \%$ of total catch in two years. Whereas the total number was caught was 1132 moths, forming about $4.27 \%$ of total catch in Motobas. Zanaty et al.(1985) found that 1694 moths/ year of $S$. exigua in Kafr El-Shiekh.

Spodoplera latebrosa was the $3^{\text {rd }}$ one with the total number of this species had been caught during the two years in Nasr city was 688 individuals, representing $2.95 \%$ of total catch, whereas the total catch of this species in Motobas was 978 moths, forming about $3.69 \%$ of total catch during the two years. The highest number of this species was 504 moths representing $3.68 \%$ of total catch in the first year in Motobas, while the lowest number was 277 forming about $2.59 \%$ in the second year in Nasr city. The moths of the predator, Eublemma gayneri caught at a percentage approximately similar to the previous species in Nasr city (Table 1), while the total number of which 710 specimens constituting $2.68 \%$ of total catch in Motobas (Table 2). The highest number of this species was recorded in the first year in Motobas, whereas the lowest number lured in the second year in Nasr city.

Percentage of Agrotis spinifera, A. ipsilon, Sesamia cretica, Autogropha gama, Earias insulana, Noctua pronuba, Helicoverpa armigera and Chryodeixis chalcites ranged between $1.01-2.19 \%$ of the total insect catch throughout the period of investigation in both regions (the moths of Athetis clavipalpis, predator Eublemma scitula and Heliothis peltigra within the same range in Kafr El-Shiekh. The other noctuid attracted species were less abundant (Table 1\&2). Mizukoshi (1999) in Japan, recorded that $A$. Ipsilon moths were not captured in large numbers by Light-traps

\section{Fam.: Oecophoridae}

This family represented by only one species, Depressaria straminella constituting $2.56 \%$ of the total catches in Nasr City. The former species was recorded for the first time here in highest numbers during the second year (322 moths) representing about $3.01 \%$. 


\section{Fam.: Plutellidae}

Family Plutellidae was represented by only one species, Plutella xylostella, with highest numbers, 1478 moths representing $6.33 \%$ of the total catch in Nasr city (Table 1). Individuals of this species (1469 moths) represented $5.55 \%$ of the total catch in Motobas. The highest numbers of this species 893 moths was trapped during the first year in Motobas (Table 2). Zanaty et al. (1985) found a few number of this species (51 moths/ year) in Kafr El-Shiekh.

\section{Fam.: Pterophoridae}

Family Pterophoridae was represented by only one species, Pterophorus monodactylus with only one moth/year in Motobas (Table 2).

\section{Fam.: Pyralidae}

Table (1) showed that family Pyralidae was represented by three species in Nasr city, were it found in relatively smaller numbers, the total numbers of this family 543 moth represented $2.33 \%$ of a total catch in Nasr city (Table 1). Echromius cambridgei, was the most abundant 332 moths constituting $1.42 \%$ of the total catch, while Pyralis galactalis, was represented by only one moth/ year for the first time here.

The results in Table (2) there are five pyralid species in Motobas, with a total numbers 1702 moths forming about $6.43 \%$ of the total catch. Chilo agamemnon, was the most abundant 395 moth represented $1.49 \%$ of the total catch in Motobas. Zanaty et al. (1985) found this species in Kafr ElShiekh (82 moths/ year).

\section{Fam.: Pyraustidae}

The data showed that family Pyraustidae were the second in rank after family Noctuidae. The former insects appeared from (Table 1\&2) were attracted at a magnitude of pyraustids moths about (12.54\%) and (17.23\%) of the total lepidopterous catch during the two years in Nasr city and Motobas respectively. The highest number of this family were caught during the second year in Motobas (2314 moths, Table 2), while the lowest number were catched during the second year in Nasr city (1273 moths, Table 1). The species, Nomophila noctuella was the previous in highest number in Nasr City (689 moths, representing $2.95 \%$ of total catch, Table 1 ). Its number was 585 , forming about $2.21 \%$ of the total catch in Motobas (Table 2). The most moths of species (436) were collected in the first year in Nasr city (Table 1). Herptogramma licarsisalis was the second pyraustid species according to its flight activity in two regions. The total number during the two years in Nasr city was 545 moths. This number formed about $2.34 \%$ of the total catch (Table 1), while the total number of this species in Motobas was 679 moths. This number formed about $2.56 \%$ of the total catch (Table 2). Pyrausta aurata was the most abundant species of this family in Motobas region. Its total number reached 959 moths constituting $3.62 \%$ of the total catch during the two years (Table 1). Ibrahim (1977) in Nasr city region found only two species of this family namely; Nomophila noctuella and Ostrina nubilalis and represent $5.8 \%$ of total catch in two years, Zanaty et al. (1985) found four species of this family in Kafr El-Shiekh with total number 488 moths/ year. 


\section{Fam.: Sphingidae}

This family was represented by only two species were attracted to the light-trap in very small numbers. These species are Agrius convolvuli convolvuli and Hyles lineata livornica. The total number of the two species reached 100 and 134 moths, representing $0.43 \%$ and $0.51 \%$ of the total attracted moths in Nasr city and Motobas respectively. Zanaty et al. (1985) in Kafr El-Shiekh found one species ( Deilephila livornica) in this family also with a few number (32 moths/ year).

\section{REFERENCES}

Badr, M. A., M. M. Salem, L. El-Said and Abdel Azim (1985a). Occurrence and fluctuation of moths at Beni-Suef as indicated by a light - trap. Proc. $6^{\text {th }}$ Arab pesticide conf., Tanta Univ., vol. (11): 159-167.

Badr, M. A., M. M. Salem, H. R. Hussein, M. A. El Samni, and M.A. Rizk(1985b). Existence and fluctuations of lepidopterus moths as indicated by a light - trap at Dakahlia, Egypt. Minia. J. Agric. Res. And Develop., 7(2): 641-657.

Dall'-Asta, U. (1997). Moths collected in the Kakamega forest (eastern Kenya), and a possible use of moths to characterise tropical forests . Metamorphosis, (Occasional Supplement 3): 98-104.

El-Bassiouny, M. H.; Salem, M. M. and Negm, F. H. (1997). Relative abundance of some lepidopterous moths attracted to a light-trap at $\mathrm{Al}$ Arish city, (Northern Sinai) during two successive years. Annals-ofAgricultural-Science-Cairo, 42(2): 643-653.

Ibrahim I. L. (1977). Stuides on the activity of some flight insects in Nasr city. M. Sc. Thesis, Fac. Agric., Al-Azhar Univ.

Mizukoshi, T. (1999). Field attractiveness of the synthetic sex pheromone of the black cutworm, Agrotis ipsilon Hufnagel (Lepidoptera: Nocutuidae) and seasonal attractant prevalence in the Oshima District of Hokkaido. Annual Report of the Society of Plant Protection of North Japan, (50): 186-189.

Nabli,-H; Bailey,-W-C; Necibi,-S (1999). Responses of Lepidoptera in Central Missouri to traps with different light sources. Journal-of-the-KansasEntomological-Society. 1999; 72(1): 82-90.

Zanaty, E.M.; Shenishen, Z.; Badr, M.A.; Salem, M.M. (1985). Survey and seasonal activity of lepidopterous moths at Kafr El-Shiekh region as indicated by Light trap. Bull: Soc. Ent. Egypte (65) 351-357 
El- Saeady, A. A. et al.

حصر لمعظم فراشـات حرشفية الأجنحة المنجذبة للمصـائد الضوئية فى منطقتين

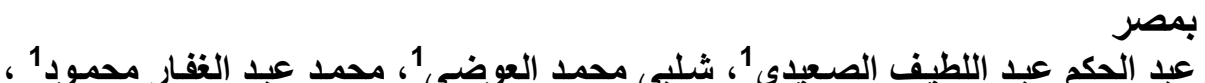

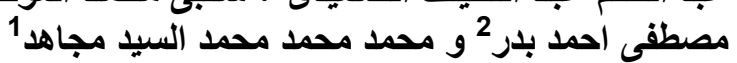

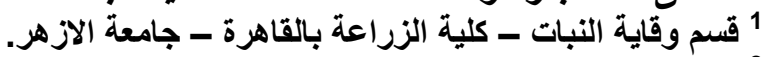

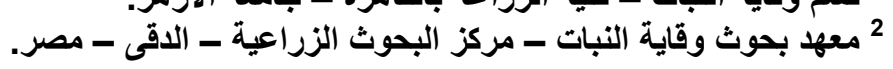

أثتملت هذه الدراسة على تتبع تتوع فر اثـات رتبة حرشفية الأجنحة وأعدادها باستخدام المصائد

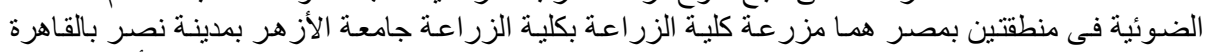

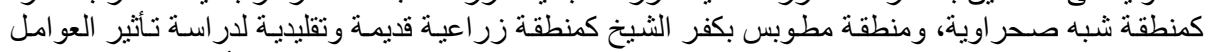

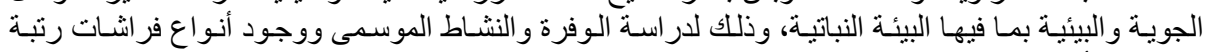

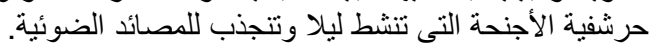

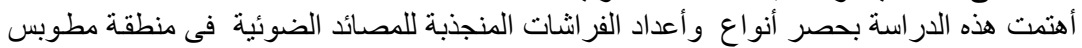

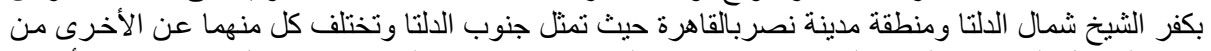

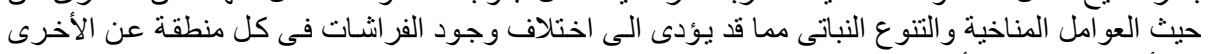

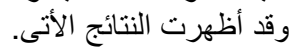

بينت الدراسة وجود 39 نو عا من فر اثنات رتبة حرشفية الأجنحة تقع تحت 11 فصيلة في منطقة

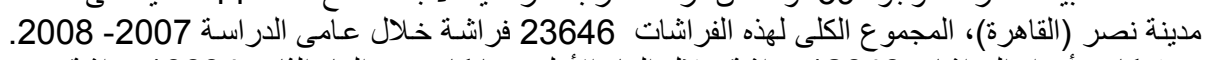

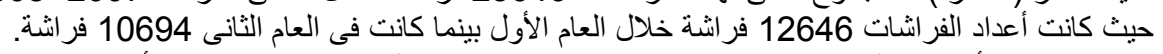

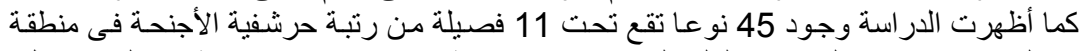

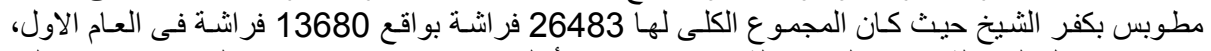

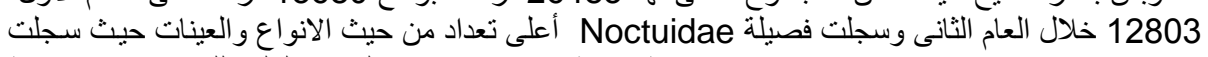

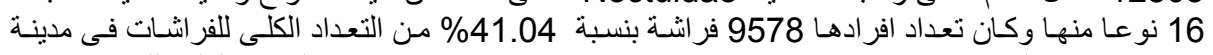

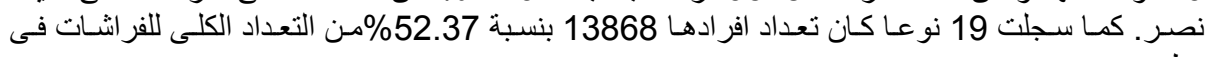

كانت دودة ورق القطن الكبرى Spodoptera littoralis أعلى الأنواع تعدادا فى كل الفصائل مطوبس.

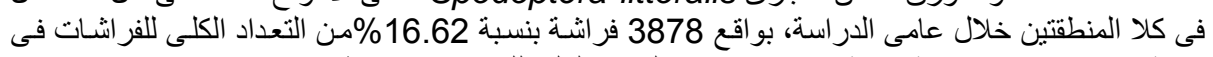

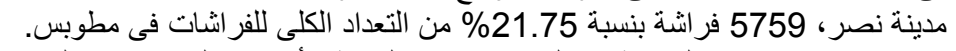

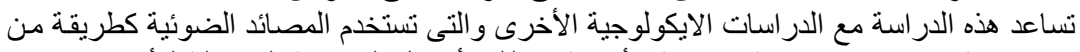

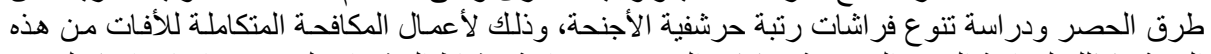

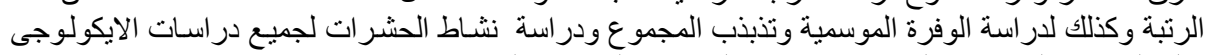

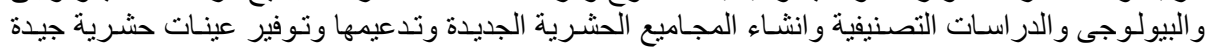

للطلبة للار اسات العليا و غيرها.

كلية الزراعة - جامعة المنصورة كلية الزراعة - جامعة الأزهر

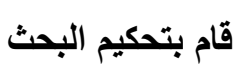

أ.د / أد إند الستار إبراهيم عبد الكريم

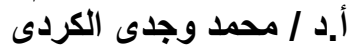

